\title{
IMPROVING BIOAVAILABILITY AND ANTHELMINTIC ACTIVITY OF ALBENDAZOLE BY PREPARING ALBENDAZOLE-CYCLODEXTRIN COMPLEXES
}

\author{
GARCÍA-RODRIGUEZ J.J.*, TORRADO J.*** BOLÁS F.*
}

\section{Summary :}

The bioavailability and anthelmintic activity of albendazolecyclodextrin complexes (ABZ-CDC) compared to albendazole suspensions in carboxymethylcellulose (ABZ-CMC) was assessed in a mouse model for Trichinella infections. Swiss CD-1 mice experimentally infected with T.spiralis were treated with both formulations against enteral (adult worms) and parenteral (migrating and encysted larvae). Oral bioavailability was assessed in age matched mice treated with $50 \mathrm{mg} / \mathrm{kg}$ of both formulations. The anthelmintic effects and plasma concentration of the active metabolite albendazole-sulphoxide (ABZSO) enantiomer (-) were significantly increased following administration of $A B Z-C D C$ in relation to $A B Z-C M C$.

KEY WORDS : albendazole, bioavailability, Trichinella, cyclodextrins

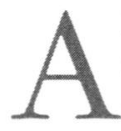
lbendazole (ABZ) is a broad spectrum antiparasitic drug acting against protozoa and helminth parasites. Following oral administration $\mathrm{ABZ}$ is quickly biotransformed in its active intermediate metabolite albendazole-sulphoxide (ABZSO) which subsequently is oxidized to the inactive form of sulphone (ABZSO2) (Gyurik et al., 1981). ABZSO exhibits chirality with two enantioneric forms present in plasma (Delatour et al., 1990). As other benzimidazolecarbamates $\mathrm{ABZ}$ is poorly soluble in water and therefore its absorption by the oral tract is reduced (Villaverde et al., 1992). In the present paper the oral bioavailability and anthelmintic activity of ABZ formulated as solid complexes in hydroxypropyl-ßs-cyclodextrin (ABZ-CDC) was evaluated in a mouse model for experimental trichinellosis.

\section{MATERIAL AND METHODS}

\section{PARASITE}

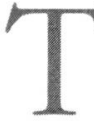
The MFEL/ES/S2 GM-1-ISS48 isolate of T. spiralis was used. The methods for infection and worm collection were those described by Denhan \& Martínez (1970).

Departmento de Parasitología* y Departamento de Farmacia y Tecnología Farmaceutica**. Facultad de Farmacia, Universidad Complutense, Spain.

Tel.: 34-91- 3941818 - Fax: 34-91-394 1815

E-mail: bolas@eucmax.sim.ucm.es

\section{DRUGS AND FORMULATIONS}

ABZ was suplied by Chemo Iberica Co (Spain). ABZ suspension was prepared in $0.5 \%$ sodium-carboxymethylcellulose (ABZ-CMC). ABZ-CDC were prepared by the co-precipitation and freeze-drying methods (Castillo et al., 1999)

\section{INFECTIONS AND TREATMENTS}

Swiss CD-1 mice aged eight weeks were purchased from Charles River, France. For anthelmintic assays animals were each infected with 300 larvae of T. spiralis and then orally treated with albendazole against three different stages of the life cycle as summarised in table I.

\begin{tabular}{lccc}
\hline \multicolumn{1}{c}{ Stage } & $\begin{array}{c}\text { Dose } \\
(\mathrm{mg} / \mathrm{kg})\end{array}$ & $\begin{array}{c}\text { Treatment } \\
(\text { Days p.i.) }\end{array}$ & $\begin{array}{c}\text { Worm counting } \\
\text { (Days p.i.) }\end{array}$ \\
\hline Adult & 5,10 & 1 & 6 \\
Migrating larvae & 50,100 & $13,14,15$ & 30 \\
Encysted larvae & 50,100 & $35,36,37$ & 45 \\
\hline
\end{tabular}

Table I. - Treatment schedule.

\section{ORAL BIOAVAILABILITY}

Age matched animals to those used for infection were treated with $50 \mathrm{mg} / \mathrm{kg}$ of ABZ-CMC or ABZ-CDC. Thereafter, five mice per each sample point were anaesthetised with $15 \%$ urethan solution and their blood collected from the heart by cardiac puncture at points $0.25,0.5,0.75,1.5,3,6,24,48$ and 72 hours post-treatment and the corresponding sera individually tested for $\mathrm{ABZ}, \mathrm{ABZSO}(+,-)$ and ABZSO 2 metabolites by HPLC (García J.J. et al., 1999).

\section{RESULTS}

The pharmacokinetic profiles of ABZSO following administration of $\mathrm{ABZ}-\mathrm{CMC}$ and $\mathrm{ABZ}-\mathrm{CDC}$ is shown in Fig. 1. Absorption was quicker when 


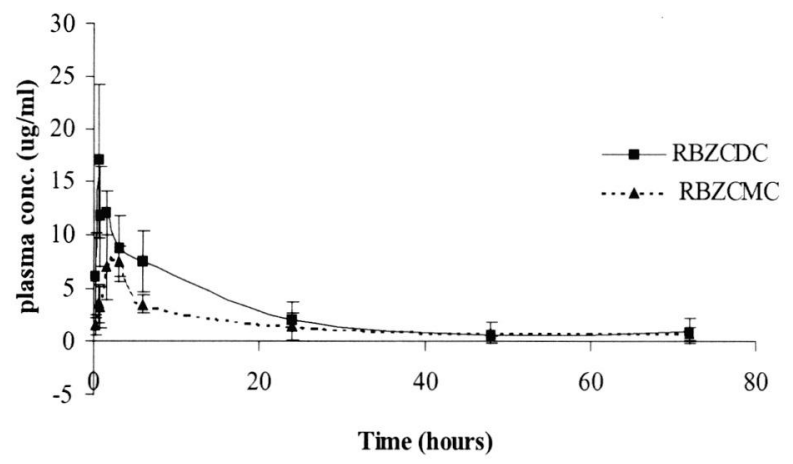

Fig. 1. - Plasma concentrations of ABZSO in plasma of mice following oral administration of $50 \mathrm{mg} / \mathrm{kg}$ of $\mathrm{ABZ}$-CMC or ABZ-CDC. Each point represent the Mean \pm standard deviation of five samples.

$\mathrm{ABZ}$ was included in $\mathrm{CDC}$ than when suspended in CMC (ABZSO Tmax $=0.5 \mathrm{~h}$ and $3 \mathrm{~h}$ respectively). ABZSO plasma concentrations achieved were significantly higher following administration of ABZ-CDC than ABZ-CMC $(\mathrm{Cmax}=16.96 \mu \mathrm{g} / \mathrm{ml}$ and $7.53 \mu \mathrm{g} / \mathrm{ml}$, AUC $=78.185 \mu \mathrm{g} . \mathrm{h} / \mathrm{ml}$ and $34.296 \mu \mathrm{g} . \mathrm{h} / \mathrm{ml}$, respectively). Plasma concentrations of $\mathrm{ABZ}$ and $\mathrm{ABZSO} 2$ were at the base level (data not shown). Administration of ABZ-CDC significantly increases the proportion of the more abundant enantiomer ABZSO (Figs 2 and 3). Comparison of anthelmintic effects of both formulations is summarised in Fig. 4.

\section{DISCUSSION}

$\mathrm{R}$ esults from this work show that cyclodextrins are good drug formulating devises as significant higher bioavailability of ABZSO is achieved when $\mathrm{ABZ}$ is administered included in cyclodextrin in relation to conventional suspension in $\mathrm{CMC}$. The higher plasma concentrations for ABZSO following treatment with ABZ-CDC could result in the increased anthelmintic effects against all stages of Trichinella life cycle, specially those against intestinal and muscular stages. This improvement in pharmacokinetics as well as in anthelmintic effects of ABZ-CDC against intestinal stages is comparable to that obtained with $\mathrm{ABZ}$ formulated in solid dispersion in PVP (Lopez et al., 1997) however ABZ-CDC complexes are easier to prepare and of higher chemical stability. The enantiomeric profiles of ABZSO are similar to those previouly reported in mice (García et al., 1999) and in rats (Delatour et al., 1990). The proportion of the supposed more abundant enantioner (-) is significantly increased following administration of $\mathrm{ABZ}-\mathrm{CDC}$ with respect to ABZ-CMC. This could indicate that this form is the main responsible for anthelmintic activity.

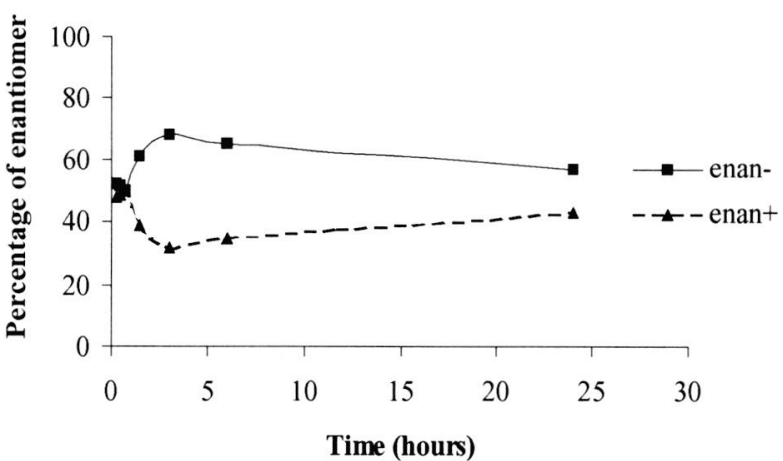

Fig. 2. - Enantiomeric separation of ABZSO in plasma of mice following oral administration of $50 \mathrm{mg} / \mathrm{kg}$ of ABZ-CMC. Each point represent the mean of five samples.

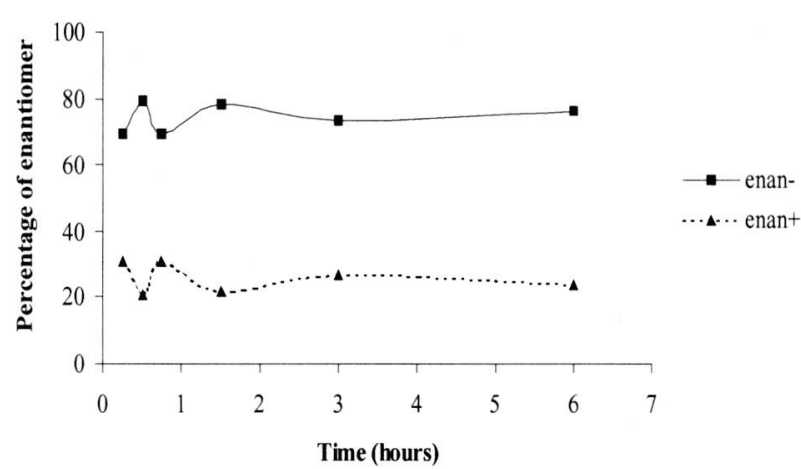

Fig. 3. - Enantiomeric separation of ABZSO in plasma of mice following oral administration of $50 \mathrm{mg} / \mathrm{kg}$ of $\mathrm{ABZ}-\mathrm{CDC}$. Each point represent the mean of five samples.

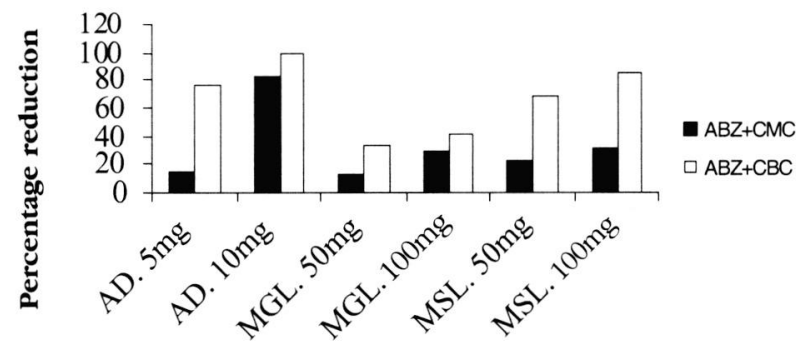

Stage and dosage

Fig. 4. - Anthelmintic activities of ABZ-CMC and ABZ-CDC against different stages. of $T$. spiralis in mice (AD: Adult worms, MGL: Migrating larvae; MSL: Encysted muscle larvae).

\section{ACKNOWLEDGEMENTS}

This work was founded by project FIS no 99/0118 


\section{REFERENCES}

Castillo J.A., Palomo-Canales J., Garcia J.J., Lastres J.L., Bolas, F. \& TORRAdO J.J. Preparation and characterization of albendazole $\beta$-cyclodextrin complexes. Drug Development and Industrial Pharmacy, 1999, 25, 1241-1248.

Delatour P., Benort E., Caude M.\& Tambute A. Species differencing the generation of the chiral sulphoxide metabolite of albendazole in sheep and rats. Chirality, 1990, 2, 156-160.

Denham D. \& Martinez A.R.M. Studies with methyridine and Trichinella spiralis. II. The use of the drug to study the rate of larval production in mice. Journal of Helmintho$\log y, 1970,44,357-363$.

Garcia J.J., Bolas-Fernandez F. \& Torrado J.J. Quantitative determination of albendazole and its main metabolites in plasma. Journal of Chromatography B, 1999, 723, 265-271.

Gyurik R. J., Chow A.W., Zaber B., Bruner E.L., Miller J. A., Villani A.J., PetKa L.A. \& Parish R.C. Metabolism of albendazole in cattle, sheep, rats and mice. Drug metabolism and disposition, 1981, 9, 503-508.

Lopez M.L., Torrado S., Torrado S., Martinez A.R. \& Bolas F. Improvement of albendazole efficacy against enteral, but not against parenteral stages of Trichinella spiralis by preparing solid dispersion in polyvinylpyrrolidone. Chemotherapy, 1997, 43, 430-435.

Villaverde C., Alvarez I., del Estal J.L. \& Prieto J.G. Albendazole and mebendazole uptake by isolated enterocytes. Dev. Pharmacol. Ther., 1992, 19, 27-31. 